\title{
1 Repeated burning alters the structure and composition of hardwood regeneration in oak-dominated
}

2 forests of eastern Kentucky, USA

3

4

5 Tara L. Keyser ${ }^{* a}$, Mary Arthur ${ }^{\mathrm{b}}$, David L. Loftis ${ }^{\mathrm{a}}$

8 a'USDA Forest Service, Southern Research Station, 1577 Brevard Road, Asheville, NC 28806,

9 tkeyser@fs.fed.us, $\underline{\text { davidloftis@ @ellsouth.net }}$

10

11

${ }^{\mathrm{b}}$ Department of Forestry, University of Kentucky, T.P. Cooper Building, Lexington, KY 40546, marthur@uky.edu

*Corresponding author: tkeyser@fs.fed.us, USDA Forest Service, Southern Research Station, 1577 
Abstract

The exclusion of anthropogenic fire is a primary factor responsible for the 'mesophication' of eastern oak

21 increasingly used to promote the establishment and growth of oak and hickory (Carya) and control

22 competition from shade-tolerant species (e.g., red maple (Acer rubrum) in the forest understory. In this

23 study, we examined the effects of fire frequency on the abundance of prominent species in the woody

24 regeneration layer in oak-dominated forests of eastern Kentucky. Treatments included: (1) fire-excluded

25 (FE); (2) frequent fire (FF) - five burns over nine years, and (3) less-frequent fire (LFF) - two burns over

26 seven years. Prior to burning (2002) and again five and seven growing seasons following the cessation of

27 burning in the FF and LFF treatments (2015), respectively, we inventoried tree species in the woody

28 regeneration layer into three size classes: (1) small seedlings (stems $<0.6 \mathrm{~m}$ ), (2) large seedlings $(\geq 0.6 \mathrm{~m}$

29 and $<1.2 \mathrm{~m}$ ) and (3) small saplings $(\geq 1.2 \mathrm{~m}$ and $<3.8 \mathrm{~cm}$ diameter at breast height). Pre- and postburn, the

30 regeneration layer was dominated by non-oak-hickory species, and although oak-hickory regeneration

31 was abundant the majority of stems were $<0.6 \mathrm{~m}$. For oak-hickory, significant treatment effects were

32 limited to the large seedling and small sapling size classes. For large oak-hickory seedlings, density was

33 significantly greater in the LFF than FE treatment. For small oak-hickory saplings, density in the LFF

34 treatment was $\sim 17$ and $\sim 4$ times greater than in the FE and FF treatments, respectively. This study

35 provides support for the notion that fire-free periods may be more of a factor controlling the abundance

36 and composition of the woody regeneration layer than simply the number of burns. However, despite

37 greater stem density, the fate of the oak-hickory regeneration layer that developed in response to the LFF

38 treatment is uncertain, as the density of non-oak competitors remains high. Additional treatments (e.g.,

39 targeted herbicide application, additional burning) may be necessary to reduce the abundance of non-oak

40 species and increase the likelihood of continued recruitment oak-hickory should natural or silvicultural

41 release events occur.

42 Keywords: Quercus; fire; mesophication; disturbance 


\section{Introduction}

44 In the eastern United States, oak (Quercus) species have been a dominant component of the forests for

45 millennia (Delcourt and Delcourt, 1997; Delcourt and Delcourt, 1998). Today, oak-hickory (Carya) is the 46 most dominant forest type in the eastern United States, comprising 34\% (57.4 million ha) of the forested

47 landbase (Oswalt et al., 2014). Changes in disturbance regimes precipitated by Euro-American settlement

48 coupled with factors that include climate variability, extirpation of species, and changes in land-use

49 interact to influence structure, composition, and regeneration potential of eastern oak-hickory (Quercus-

50 Carya) forests (Gragson and Bolstad, 2006; McEwan et al., 2011). In Appalachian hardwood forests, a

51 relatively low disturbance frequency over the last century (Hart and Grissino-Mayer, 2008; Hart et al.,

52 2012) has facilitated the development of dense understories (i.e., sapling and midstory) and hastened the

53 succession of these forests towards shade-tolerant species such as red maple (Acer rubrum), sugar maple

54 (A. saccharum), blackgum (Nyssa sylvatica), and American beech (Fagus grandifolia) (Hart and

55 Grissino-Mayer, 2008). The ecological and economic ramifications associated with the gradual

56 replacement of oak forests to those dominated by non-oak species (Fei et al., 2011) are wide-ranging and

57 include decreased water yield (Caldwell et al., 2016) and direct and indirect effects on population

58 dynamics of game and non-game wildlife species (McShea et al., 2007).

Although a multitude of interacting forces control stand dynamics and successional patterns

60 (McEwan et al., 2011), fire, or more accurately, lack thereof, is often identified as the primary factor

61 responsible for the 'mesophication' of eastern oak forests and associated oak regeneration and recruitment

62 problems (Abrams, 1992; Nowacki and Abrams, 2008). Dendroecology (Shumway et al., 2001; McEwan

63 et al., 2007), paleoecology (Delcourt et al., 1998; Fesenmyer and Christensen, 2010), and witness tree

64 (Thomas-Van Gundy and Nowacki, 2013) studies provide evidence that periodic fire (mean fire return

65 interval of 7.7 years (range $1-29$ years); Lafon et al., 2017) was a factor contributing to the development

66 and maintenance of oak-hickory forests across varying spatial and temporal scales, with the increase in

67 the abundance of shade-tolerant species and onset of oak regeneration problems correlated with fire

68 exclusion and suppression efforts in the early to mid-1900s (Shumway et al., 2001; Lafon et al., 2017). As 
such, reintroduction of fire, with frequency, intensity, and seasonality of burns informed by historic fire

70 regimes (e.g., Guyette et al., 2006; Flatley et al., 2013; Aldrich et al., 2014), is actively integrated into

71 forest management plans on public and private lands.

72 Successful oak regeneration and recruitment following disturbance is dependent upon the

73 existence of a large number of competitive (i.e., large) oak seedlings in the forest understory prior to

74 disturbance (Sander, 1972; Loftis 1990a). In Appalachian hardwood forests, oak seedlings, which are

75 only moderately tolerant of shade, are unable to develop into larger and more competitive size classes

76 under dense shaded understories (Crow, 1992; Loftis, 1990b; Lorimer et al., 1994). Thus, small seedlings,

77 which dominate the forest understory, are unable to compete with shade-tolerant species already present

78 in the woody regeneration layer or new seedlings of species such as yellow-poplar (Liriodendron

79 tulipifera) and sweet birch (Betula lenta) that establish following canopy-reducing disturbance(s) (Loftis,

80 1983; Miller et al., 2006). There are numerous critical processes associated with the oak regeneration

81 process - flowering and acorn production, germination and seedling establishment, seedling development,

82 and overstory recruitment - where disturbance, including prescribed fire, may alter the probability of

83 successful regeneration (Arthur et al., 2012). Fire may be of particular importance to the development of

84 larger competitive oak and hickory seedlings by controlling stem density and resultant light availability

85 and reducing competition from non-oak species in the woody regeneration layer (Van Lear and Waldrop,

86 1989; Brose, 2014).

87 Short-term results (e.g., $<3$ growing seasons post-fire) from prescribed fire studies in eastern

88 mixed-oak forests suggested repeated burning at regular intervals does little to enhance oak and hickory

89 seedling development or control competition from shade-tolerant species in the woody regeneration layer

90 (Hutchinson et al., 2005; Blankenship and Arthur, 2006; Alexander et al., 2008). Mechanisms underlying

91 fire's limited impact include only minor effects on stand structure and resultant understory light

92 availability and rapid and prolific sprouting of top-killed non-oak individuals (Arthur et al., 1998; Chiang

93 et al., 2005; Iverson et al., 2008). Since publication of these early studies, understanding of the intricacies

94 of the role of fire in establishing and maintaining present-day oak forests has advanced. For example, 
retrospective (Dey and Guyette, 2000; Signell et al., 2005; McEwan et al., 2007) and manipulative field

96 studies (Peterson and Reich, 2001; Hutchinson et al., 2012b; Knapp et al., 2016) from oak-dominated

97 systems suggest spatial variability in fire occurrence and temporal variability in fire frequency and

98 corresponding fire-free periods and fire severity act as ecological filters selecting species with

99 regeneration traits adapted to local and regional fire regimes (Pausas et al., 2004; Myers and Harms,

100 2011; Hollingsworth et al., 2013). In upland oak-hickory forests regeneration traits favored by fire are

101 typified by oak and hickory species, and include high root to shoot ratios (Kolb et al., 1990), hypogeal

102 germination, and superior sprouting and growth following top-kill (Brose et al., 2013).

103 Forests of the Cumberland Plateau are comprised of a diverse suite of species that represent a

104 variety of life history and functional traits. Although species composition varies with topography and

105 associated gradients in moisture availability, upland oak-hickory forest types dominate the landscape

106 (McNab, 2011). Similar to other eastern oak forests, land-use history and a decrease in the frequency of

107 exogenous disturbance events has, in part, created forest conditions less favorable to regeneration and

108 recruitment of oak and hickory species, particularly on more productive mesic sites where securing oak

109 regeneration is particularly problematic (Loftis, 1990a; Schweitzer and Dey, 2011). Consequently, the

110 reintroduction of fire is increasingly viewed as a tool managers can use to promote the establishment and

111 development of fire-adapted tree species, including oak and hickory, in the forest understory and to

112 facilitate eventual recruitment into the forest canopy (Brose, 2014). The primary objective of this study

113 was to examine the effects of alternative prescribed fire regimes characterized by frequent fire versus less

114 frequent fire on the abundance of prominent species groups in the regeneration layer across a

115 topographically complex landscape characterized by a productivity or moisture availability gradient.

116 Given the longer-term nature of this study, we hypothesized: (H1) Oak and hickory in the woody

117 regeneration layer will increase in abundance in response to fire, with the greatest increase occurring as a

118 result of more frequent fire; (H2) Fire will reduce the abundance of shade-tolerant species in the woody

119 regeneration layer, with the greatest reduction occurring as a result of more frequent fire; and (H3) the

120 effects of fire, regardless of fire frequency, will vary across the landscape, with the greatest effects on the 
121 density and size distribution of woody regeneration occurring on more xeric, less productive portions of 122 the landscape.

\section{2. Materials and Methods}

125 2.1. Study site

126 This study was conducted on the Cumberland Ranger District of the Daniel Boone National Forest

127 located in the Cumberland Plateau Physiographic Province in eastern Kentucky $\left(38.1^{\circ} \mathrm{N}, 83.5^{\circ} \mathrm{W}\right)$.

128 January and July mean daily temperature (30-year normal, $1981-2010)$ is $2{ }^{\circ} \mathrm{C}$ and $24.6{ }^{\circ} \mathrm{C}$, respectively

129 (http://www.ncdc.noaa.gov.). Mean annual precipitation is approximately $\sim 1250 \mathrm{~mm}$

130 (http://www.ncdc.noaa.gov). Topography is varied, with elevations between $260 \mathrm{~m}$ and $360 \mathrm{~m}$ and slopes

131 ranging from $0 \%$ to $75 \%$. Soils throughout the study area are classified as Typic Hapludults, Typic

132 Hapludalfs, Ultic Hapludalfs, and Typic Dystrochrepts (Avers, 1974). On ridges and steep slopes, soils

133 are typically loamy to clayey, possess low soil moisture holding capacity, and are low in fertility, while

134 soils on lower slopes, coves, and terraces are characterized by higher organic matter and greater soil

135 moisture holding capacity (Jones, 2005).

136 Forests within the study area are second-growth forests that range in age from 80 to 110 years.

137 These forests originated from heavy cutting in the early $20^{\text {th }}$ century and have experienced fire

138 exclusion/suppression and minimal disturbance over the $80+$ years of stand development. White oak

139 (Quercus alba) site index (base-age 50) varied with topographic position and aspect, and ranged from 15

$140 \mathrm{~m}$ to $34 \mathrm{~m}$. Prior to treatment, basal area (BA) and stem density of the overstory layer (stems $\geq 20 \mathrm{~cm}$

141 diameter at $1.37 \mathrm{~m}$ above groundline (dbh)) averaged $21.7 \mathrm{~m}^{2} \mathrm{ha}^{-1}$ and $211 \mathrm{stems} \mathrm{ha}^{-1}$, respectively, and

142 BA and stem density of the midstory layer (stems $10-20 \mathrm{~cm}$ dbh) averaged $4.0 \mathrm{~m}^{2} \mathrm{ha}^{-1}$ and 249 stems ha $^{-}$

$143{ }^{1}$, respectively (Arthur et al., 2015). Across the study area, oak and hickory species combined represented

$14434 \%$ and $80 \%$ of the pre-treatment midstory and overstory BA, respectively (Arthur et al. 2015). The

145 sapling layer (stems $2-10 \mathrm{~cm} \mathrm{dbh)} \mathrm{was} \mathrm{comprised} \mathrm{of} \mathrm{shade-tolerant} \mathrm{species,} \mathrm{including} \mathrm{red} \mathrm{maple,} \mathrm{sugar}$ 
maple (Acer saccharum), serviceberry (Amelanchier arborea), blackgum (Nyssa sylvatica), and sourwood

147 (Oxydendrum arboreum).

\subsection{Experimental design and data collection}

150 Three blocks (Wolf Pen, Chestnut Cliffs, and Buck Creek), each between 200 and 300 ha, were located

151 on the Cumberland Ranger District. Each block was divided into three stands, each between 58 and 116

152 ha. One of three treatments was randomly assigned to each of the three experimental units in each block.

153 Treatments were: Fire-Excluded (FE), Frequent Fire (FF), and Less Frequent Fire (LFF). Between 8 and

15412 measurement plots were established within each of the nine stands. During the course of this study, 5

155 of the 10 FE plots in the Wolf Pen block and 1 of the 11 FE plots in the Buck Creek block were

156 accidentally burned during unplanned fire and were, therefore, removed from analyses. Plots were $10 \mathrm{~m} \mathrm{X}$

$15740 \mathrm{~m}$ (0.04 ha), with the long axis oriented parallel to the contour. Species composition of stems $\geq 2 \mathrm{~cm}$

158 dbh recorded prior to treatment (Arthur et al., 2015) was used to categorize plots into one of three

159 moisture classes: Subxeric, Intermediate, or Submesic (McNab et al., 2007; McNab and Loftis, 2013).

At the center of each plot, a 0.004 ha circular subplot was established in which tree regeneration

161 was inventoried by species (up to a maximum of 25 individuals per species*size class combination in a

162 given 0.004 ha regeneration subplot) in the following size classes: (1) small seedlings (stems $<0.6 \mathrm{~m}$ in

163 height); (2) large seedlings (stems $\geq 0.6 \mathrm{~m}$ in height but $<1.2 \mathrm{~m}$ in height); and (3) small saplings (stems

$164 \geq 1.2 \mathrm{~m}$ in height but $<3.8 \mathrm{~cm} \mathrm{dbh}$ ). These size classes were chosen to reflect the positive relationship

165 between oak and hickory regeneration potential and seedling/sapling size (Loftis 1990a) and to maintain

166 consistency among other prescribed burning and silvicultural studies being conducted in the region (e.g.,

167 Schweitzer and Dey, 2015). Top-killed stems with multiple basal sprouts were recorded as one individual.

168 Sampling of the tree regeneration pool (stems $<3.8 \mathrm{~cm} \mathrm{dbh}$ ) occurred in 2002 (pretreatment) and 2015.

169 Prescribed burns were implemented by the USDA Forest Service. All fires were conducted

170 between March $24^{\text {th }}$ and April $18^{\text {th }}$. For the FF treatment, five prescribed burns were conducted over a

171 nine year period, occurring in 2003, 2004, 2006, 2008, and 2011. For the LFF treatment, two burns were 
172 conducted over a seven year period in 2003 and 2009. No manipulation of vegetation occurred in the FE

173 treatment. In 2003, prescribed burns in two of the three blocks were aerially ignited. All other burns were

174 ignited via drop torches. Specific information regarding burn logistics (e.g., ignition patterns, weather,

175 and fuel moisture conditions), fire temperatures, and direct fire effects for all but the most recent burn

176 conducted in 2011 are detailed by Arthur et al. (2015).

177 We did not monitor the establishment of new individuals via seed or root suckering, nor did we

178 monitor an individual seedling's survival and growth. This is an important limitation, as the changes in

179 the size distribution and composition of the woody regeneration layer reported here could be masked by

180 species-specific patterns of seedling establishment, survival, and growth along with basal sprouting of

181 top-killed stems (Wang et al., 2005; Alexander et al., 2008; Royse et al., 2010). Because of this, our

182 results reflect a point-in-time description of the effects of treatment and moisture class on the woody

183 regeneration layer.

185 2.3. Data analysis

186 We used a linear mixed-effects model under a split-plot repeated measures design to analyze

187 absolute density (stems ha ${ }^{-1}$ ) of small and large seedlings and small saplings in 2002 and 2015 for each of

188 the five species groups identified in Table 1 (Maples, Oak-Hickory, Other, Sassafras, and Tolerant).

189 Similarly, we analyzed relative density of species groups within the small sapling layer. For each analysis,

190 treatment (FE, FF, LFF) was the whole-plot factor, moisture class (Subxeric, Intermediate, Submesic)

191 was the split-plot factor, and year was the repeated factor. Treatment, moisture class, and year along with

192 all possible interactions were fixed effects and block and block*treatment were random effects. The

193 covariance structure used to account for repeated measurements was compound symmetry or

194 heterogeneous compound symmetry. Analyses were conducted using the MIXED procedure in SAS v. 9.4

195 (SAS Institute, 2011). The GROUP option was utilized to specify heterogeneity in the residual covariance

196 (grouping factors included moisture class, treatment, treatment*year, or moisture class*year depending on

197 the species group-size class combination analyzed) (Littell et al., 2006). Significant interactions were 
examined using the SLICE option. Following significant $F$-tests, or partitioned $F$-tests in the case of

199 interactions, differences among least-square means were detected using Fishers Least Significant

200 Difference. When necessary, data were square-root transformed to achieve normality and

201 homoscedasticity. Analyses were significant at alpha $=0.05$.

\section{3. Results}

\section{3.1. General characteristics of the woody regeneration layer}

204 Across treatments, moisture classes, and species groups, the density of the woody regeneration layer 205 averaged 22,558 and 30,096 stems ha ${ }^{-1}$ in 2002 and 2015, respectively. Before and after treatments,

206 woody regeneration was dominated by shade-tolerant species, with the Maple and Tolerant species groups 207 comprising an average of $43 \%$ of the woody regeneration layer over the course of the study. In 208 comparison, species in the Oak-Hickory group constituted only $22 \%$ and $28 \%$ of the woody regeneration 209 layer in 2002 and 2015, respectively. Small seedlings $(<0.6 \mathrm{~m}$ tall) dominated the regeneration layer in 210 each species group, representing $92 \%$ of the regeneration layer in 2002 and $75 \%$ of the woody

211 regeneration layer in 2015 (Fig. 1). The Sassafras group experienced the greatest proportional increase in 212 the combined large seedling and small sapling size classes, increasing from $11 \%$ in 2002 to $44 \%$ in 2015.

213 In contrast, the Maple group experienced the lowest proportional increase in the combined large seedling 214 and small sapling layers, increasing from 6\% to $10 \%$ between 2002 and 2015.

\section{3.2. Small seedlings}

216 Fire, regardless of frequency or moisture class, had no effect on the density of small seedlings for any of

217 the five species groups (Table 2). Across treatments and moisture classes, small seedling density of Oak218 Hickory in 2015 was greater by 2354 seedlings ha ${ }^{-1}$ than in 2002 while small seedling density of Sassafras 219 in 2015 was lower by 1090 seedlings ha $^{-1}$ than in 2002 (Table 3). Absolute density of small seedlings for 220 the Oak-Hickory, Other, and Sassafras species groups varied across moisture classes (Table 2). Across 221 years and treatments, absolute density of small seedlings for the Oak-Hickory and Sassafras groups was 
222 significantly greater on the Subxeric and Intermediate versus Submesic portions of the landscape. For the

223 Other species group, absolute small seedling density increased as moisture availability increased (Table

224 3). Small Maple seedling density was $1417 \mathrm{ha}^{-1}$ greater on Subxeric sites in 2015 than in 2002, but did not

225 vary significantly among the moisture classes in either year.

\subsection{Large seedlings}

227 Fire significantly affected the absolute density of large Oak-Hickory seedlings (stems $\geq 0.6 \mathrm{~m}$ and $<1.2 \mathrm{~m}$

228 tall), and this effect varied by year (Table 2). In 2002, prior to treatment, large Oak-Hickory seedling

229 density averaged only 49 stems $^{-1} \mathrm{a}^{-1}$ across the FE, FF, and LFF treatments. Large Oak-Hickory seedling

230 density increased between 2002 and 2015 in both the FF and LFF treatments (Fig. 2a). However, by

2312015 , large Oak-Hickory seedling density was significantly greater only in the LFF treatment compared

232 to the FE treatment, with large Oak-Hickory seedlings averaging 189, 752, and $1310 \mathrm{ha}^{-1}$ in the FE, FF,

233 and LFF treatments, respectively. Regardless of frequency, fire had no significant impact on the density

234 of large seedlings in the Maple, Other, Sassafras, and Tolerant species group, However, significantly

235 greater large seedling density in 2015 than in 2002 for these four competitor species groups provides

236 evidence of recruitment into this size class regardless of treatment or moisture class (Fig. 3). Large Oak-

237 Hickory seedling density varied across moisture classes, but only in 2015. In 2002, large Oak-Hickory

238 seedling density averaged $55 \mathrm{ha}^{-1}$ on Subxeric, Intermediate, and Submesic sites (Fig. 2b). By 2015, large

239 Oak-Hickory seedling density on Subxeric and Intermediate sites averaged $1111 \mathrm{ha}^{-1}$ and was

240 significantly greater than on Submesic sites where large seedlings averaged only $257 \mathrm{ha}^{-1}$.

\section{$241 \quad 3.4$. Small saplings}

242 Regardless of frequency, fire had no significant impact on the density of small saplings in the

243 Maple, Other, and Tolerant species group, however, significant increases in small sapling density between

2442002 and 2015 suggests recruitment into the small sapling size class occurred regardless of treatment or

245 moisture class (Fig. 4). Fire significantly affected the absolute density of small (stems $\geq 1.2 \mathrm{~m}$ tall and 
$246<3.8 \mathrm{~cm} \mathrm{dbh}$ ) Oak-Hickory saplings, and this effect varied by year (Table 2). In 2002, prior to treatment,

247 small Oak-Hickory and Sassafras sapling density averaged only 24 stems $^{-1} a^{-}$across the FE, FF, and LFF

248 treatments. Oak-Hickory small sapling density increased between 2002 and 2015 in both the FF and LFF

249 treatments (Fig. 5a). However, by 2015, only the LFF treatment possessed small Oak-Hickory sapling

250 densities in excess of that observed in the FE treatment, with small Oak-Hickory saplings averaging 45,

251201 , and $754 \mathrm{ha}^{-1}$ in the FE, FF, and LFF treatments, respectively. Small Oak-Hickory sapling density

252 varied across moisture classes, but only in 2015 (Table 2, Fig. 5b). In 2002, small Oak-Hickory saplings

253 averaged $25 \mathrm{ha}^{-1}$ on Subxeric, Intermediate, and Submesic sites. By 2015, small Oak-Hickory sapling

254 density on Subxeric sites averaged $714 \mathrm{ha}^{-1}$ and was significantly greater than on Submesic sites where

255 small saplings averaged $125 \mathrm{ha}^{-1}$.

Fire significantly affected the absolute density of small Sassafras saplings, and this effect again

257 varied by year (Table 2). In 2002, prior to treatment, small Sassafras sapling density averaged only 90

258 stems ha ${ }^{-1}$ across the FE, FF, and LFF treatments. For Sassafras small sapling density increased between

2592002 and 2015 in both the FF and LFF treatments (Fig. 5a). Small Sassafras saplings in both FF and LFF

260 increased relative to the FE treatment, with small sapling density on average 11.7 times greater in the FF

261 and LFF treatments than FE treatment.

Regardless of frequency, fire had no effect on the relative density of the Maple, Oak-Hickory,

263 Other, and Tolerant species groups in the small sapling layer (Table 2). Only for Sassafras did relative

264 density in the small sapling layer change, increasing significantly from 3\% in the FE to an average of

$26523 \%$ in the FF and LFF treatments (Table 4). Irrespective of treatment and moisture class, relative density

266 of Oak-Hickory, Other, and Sassafras species groups in the small sapling layer increased significantly

267 between 2002 and 2015 (Table 4) relative to that of Maple which declined from 33\% in 2002 to $12 \%$ in

268 2015. Relative density of Oak-Hickory and Other species groups in the small sapling layer varied across

269 moisture classes, with relative density of Oak-Hickory greatest on Subxeric sites and lowest on Submesic 
270 sites (Table 4). In comparison, relative density of the Other species group in the small sapling layer was

271 greatest on Submesic and Intermediate sites and lowest on Subxeric sites.

\section{4. Discussion}

273 This study is one of only a few (e.g., Hutchinson et al., 2012a; 2012b; Waldrop et al. 2016) to

274 quantify the effects of repeated burns conducted at the landscape-level after a relatively long fire-free

275 interval ( $\geq 5$ years) on the woody regeneration layer in mature, mixed-oak forests. Prior to and after the

276 cessation of burning, the woody regeneration layer was dominated by species other than Oak-Hickory; a

277 condition typical of mature second-growth upland hardwood forests in the Cumberland Plateau (Arthur et

278 al., 1998; McEwan et al., 2005; Blankenship and Arthur, 2006; Hart and Grissino-Mayer, 2008).

279 Furthermore, although Oak-Hickory seedlings were abundant, particularly on Subxeric and Intermediate

280 moisture classes, the vast majority of seedlings were $<0.6 \mathrm{~m}$. Within the woody regeneration layer, large

281 seedlings and small saplings, regardless of species, represent the individuals most likely to successfully

282 compete (i.e., achieve presence in the dominant/co-dominant canopy layers) following overstory

283 disturbance (Sander and Graney, 1992; Loftis 1990a). For large seedlings and small saplings, we found

284 partial support for our hypothesis (H1) that Oak-Hickory in the woody regeneration layer would increase

285 in abundance in response to fire. However, we found the LFF treatment, not the FF treatment as

286 hypothesized, provided the greatest benefit to Oak-Hickory. Relative to the FE treatment, we documented

287 an increase of 1121 large Oak-Hickory seedlings ha ${ }^{-1}$ and 709 small Oak-Hickory saplings ha ${ }^{-1}$ in the LFF

288 treatment, while large seedling and small sapling density remained similar between the FE and FF

289 treatments. Data regarding the medium (i.e., 5 years) and long-term (i.e., >10 years) effects of landscape-

290 level repeated burning on the woody regeneration layer in mixed-oak forests are sparse and results

291 inconsistent across studies. In southern Ohio, Hutchinson et al. (2012a) observed three and five burns

292 conducted over a 10-year period increased absolute and relative density of Oak-Hickory in the small

293 sapling layer (

294 contrast, two growing seasons after burning concluded, Blankenship and Arthur (2006) found the 
competitive status of sapling-sized oaks (stems $>50 \mathrm{~cm}$ tall and $<2 \mathrm{~cm} \mathrm{dbh}$ ) in the forest understory had

296 not improved over the course of nine years and three burns. In the southern Appalachians, Waldrop et al.

297 (2016) found repeated burning (three burns conducted over a 12-year period) significantly increased the

298 density of oak seedlings $(<1.4 \mathrm{~m}$ tall $)$ in the forest understory, however, the density of competitor species

299 seedlings remained high (47\% - 340\% greater than oak seedling density). The authors report similar

300 results with mechanical thinning following by repeated burning suggesting herbicide application and/or

301 growing season burning (Brose et al., 1999) may be necessary to reduce the abundance and sprouting of

302 competitor species.

303 The failure of the FF treatment to promote recruitment of Oak-Hickory into large seedling or

304 small sapling size classes despite the similarity of overstory, midstory, and large sapling density between

305 the FF and LFF treatments (Arthur et al., 2015) combined with disparate results among repeated burn

306 studies (e.g., Blankenship and Arthur, 2006; Hutchinson et al., 2012a) suggests the fire-free period, or

307 antecedent periods between fires (sensu Arthur et al., 2015), plays an important role in Oak-Hickory

308 seedling development and recruitment. In this study, post-treatment data were collected five and seven

309 growing seasons after burning ceased in the FF and LFF treatments, respectively, suggesting differential

310 effects of FF and LFF treatments on larger Oak-Hickory stems may be as much a function of the fire-free

311 period specific to each treatment as fire frequency per se. Oaks display a conservative growth strategy

312 whereby carbon is proportionally allocated to belowground versus aboveground growth (Kolb et al.,

313 1990) which, coupled with dormant basal buds located below the soil surface, confers superior sprouting

314 and growth following top-kill relative to mesophytic, shade-tolerant species (Brose et al., 2013). Despite

315 these characteristics, high frequency fire that results in recurrent top-kill and sprouting can restrict

316 seedling development into more fire-resistant size classes and eventual recruitment (Alexander et al.,

317 2008; Peterson and Reich, 2008; Knapp et al., 2015). In comparison, fire regimes characterized by less

318 frequent fire and relatively long fire-free periods permit the recovery of biomass and facilitate recruitment

319 into larger, more fire-resistant and competitive size classes (Peterson and Reich, 2001). Once a pool of

320 competitive oaks develop, Dey (2014) suggests a fire-fire period between 10 and 30 years will be required 
321 for recruitment into the midstory and overstory canopy layers. However, under an intact forest canopy

322 fire-free periods as low as 14 years may also allow non-Oak-Hickory species, including red maple,

323 sourwood, and blackgum, to develop into size classes resistant to future fire mortality (Harmon, 1984;

324 Signell et al., 2005). In contemporary forests, there appears to be a trade-off between the need to control 325 the density of non-Oak-Hickory competitors via frequent burning (e.g., Knapp et al., 2016) and the fire-

326 free period essential to the post-fire recovery and recruitment of Oak-Hickory in the woody regeneration 327 layer.

328 Critical to the recruitment of Oak-Hickory species in the woody regeneration layer following fire 329 is the abundance and size of competing species. In this study, we found no support for our hypothesis $330(\mathrm{H} 2)$ that fire, and, more specifically frequent fire, would reduce the abundance of non-Oak-Hickory 331 species in the woody regeneration layer. Regardless of size class, the FF and LFF treatments were 332 ineffective at reducing the abundance of non-Oak-Hickory competitors. In fact, across treatments and 333 moisture classes, absolute density of large seedlings and small saplings for all species groups other than 334 Maple and relative density of all species groups other than the Tolerant group were significantly greater in 3352015 , five to seven growing seasons after burning ceased, than in 2002. The lack of treatment effects on 336 small sapling-sized Maple and Tolerant species is likely related to the continued and often vigorous 337 sprouting of top-killed stems in the large sapling and midstory layers in both burn treatments (Hutchinson 338 et al., 2012a; Arthur et al., 2015). Although the increase in the absolute density of small Sassafras 339 saplings observed in both the FF and LFF treatments was significant, intolerance of shade and relatively 340 short lifespan (Burns and Honkala, 1990) suggest it will have minimal impact on the development and 341 recruitment of both Oak-Hickory and non-Oak-Hickory species in the woody regeneration layer.

342 Fire behavior varies across a topographically complex landscape, with greater fire intensity 343 occurring on poor quality, xeric locations (e.g., ridgetops, south-facing slopes) versus highly productive, 344 mesic (e.g., coves, north-facing slopes) portions of the landscape (Elliott et al., 1999; Iverson et al., 2004).

345 The effects of this variability in fire intensity often manifest in more pronounced changes in stand 346 structure with decreasing productivity and moisture availability (e.g., Albrecht and McCarthy, 2006; 
347 Iverson et al., 2008). In our study, treatment effects, although variable across species groups and years,

348 did not vary across moisture classes (i.e., no significant interaction between treatment and moisture class),

349 providing no support for our hypothesis (H3) that changes in the abundance and composition of the

350 woody regeneration layer, regardless of fire frequency, would be more pronounced on Subxeric versus

351 Submesic sites (H3). Our results are in contrast to prescribed burning studies in mixed-oak forests in

352 southern Ohio. For example, following thinning and repeated burning, Iverson et al. (2008) noted that

353 changes in the abundance of seedlings (stems $<1.4 \mathrm{~m}$ tall) and small saplings (stems $\geq 1.4 \mathrm{~m}$ tall and $<3.0$

$354 \mathrm{~cm} \mathrm{dbh}$ ) of red maple, yellow-poplar, oak and hickory, and sassafras were more pronounced on dry and

355 intermediate sites than mesic sites after a two year (growing season) fire-free period. Similarly, in mixed-

356 oak forests of southern Ohio, Hutchinson et al. (2012a) documented that positive effects of repeated

357 burning, after a three or four year fire-free period, on the absolute and relative abundance of oak and

358 hickory in the small sapling (stems $1.4 \mathrm{~m}$ tall to $<3.0 \mathrm{~cm} \mathrm{dbh}$ ) layer were limited to dryer portions of the

359 landscape, with no positive effects observed on mesic sites. Again, however, differences in fire-free

360 periods between the current study and others (e.g., Iverson et al., 2008; Hutchinson et al., 2012a) are a

361 confounding factor limiting direct comparison of results among studies. In this study, the expert system

362 used to differentiate moisture classes, which was based on pre-treatment species composition, indicated

363 clear discrimination between Subxeric and Submesic plots, with substantial overlap observed between

364 Intermediate plots and Subxeric and Submesic plots (McNab et al. 2007). This coarse filter approach to

365 assessing moisture/productivity gradients may explain, in part, the lack of interaction between moisture

366 class and burn treatment. A more direct and objective method of assessing moisture/productivity that uses

367 a combination of topographic (i.e., slope, aspect, curvature) and soils (i.e., water holding capacity) data

368 (e.g., the Integrated Moisture Index; Iverson et al., 1997) may better quantify landscape-level

369 moisture/productivity gradients and, therefore, increase sensitivity to burn treatments (Iverson et al., 370 2007).

\section{$371 \quad$ 5. Conclusions}


372 Oak regeneration, or more specifically, oak recruitment, from the woody regeneration layer into the 373 subcanopy, midstory, and, eventually, canopy layers continues to be problematic across the eastern US 374 (Dey, 2014; Lafon et al., 2017). There is growing recognition that frequent disturbance, including fire, 375 was a critical force shaping pre-European and modern day structure and composition (Abrams, 1992;

376 McEwan et al., 2011). Changes in land-use have resulted in disturbance regimes characterized by low 377 frequency and low severity disturbance events (Buchanan and Hart, 2012) and, correspondingly, forest 378 structures less conducive to the sustained recruitment of Oak-Hickory species across the landscape (Hart 379 et al., 2012). Although recent research efforts have focused on fire frequency as a primary factor 380 controlling woody vegetation response to prescribed burning, the results of our study suggest the intricate 381 interactions of fire frequency and corresponding fire-free periods may be more of a factor controlling the 382 abundance and composition of the woody regeneration layer following burning than simply the number of 383 burns. In addition to the interplay between fire frequency and fire-free periods, there is increasing 384 recognition of the role the seasonality of burning may have on the composition of the woody regeneration 385 layer in oak-dominated forests. A meta-analysis by Brose (2013) suggests that growing season burns 386 conducted under an intact canopy actually increases mortality of Oak-Hickory in the woody regeneration 387 layer relative to mesophytic competitors. In contrast, under reduced canopy cover, the authors report oak 388 survival as well as relative abundance in the woody regeneration layer is greater following growing 389 versus dormant season burning. Clearly, the factors associated with the reintroduction of fire to long 390 undisturbed oak forests are innumerable, and the potential for interactions among abiotic and biotic 391 factors great.

At our study sites, Arthur et al. (2015) found both FF and LFF treatments were effective at 393 reducing density in the sapling and midstory layers, although overstory density remained similar to 394 unburned stands. High overstory density, particularly on Submesic portions of the landscape (Arthur et 395 al., 2015), will likely restrict recruitment of the large Oak-Hickory and/or small Oak-Hickory saplings 396 that developed in response to the LFF treatment and promote the continued development of non-Oak- 
397 Hickory competitors in the forest understory. In comparatively dry oak forests of the Ozark Highlands,

398 Larsen et al. (1997) found overstory ( $\mathrm{stems} \geq 15 \mathrm{~cm} \mathrm{dbh}$ ) basal area as low as $6.5 \mathrm{~m}^{2} \mathrm{ha}^{-1}$ reduced the

399 probability of adequate oak seedling stocking. Similarly, in south central Pennsylvania, Signell et al.

400 (2005) noted the development and recruitment of oak into the sapling ( $>1.45 \mathrm{~m}$ tall and $<7.62 \mathrm{~cm} \mathrm{dbh})$

401 size class became significantly restricted when overstory and understory (i.e., suppressed trees) density

402 exceeded 400 and 200 trees $^{-1}{ }^{-1}$, respectively. In old-growth oak forests, stand reconstruction studies

403 suggest fire interacted with canopy-reducing disturbance events to facilitate the development and

404 recruitment of oak across the landscape (Rentch et al., 2003a; 2003b). Correspondingly, in contemporary

405 secondary mixed-oak forests, Hutchinson et al. (2012b) observed significantly more abundant large oak

406 regeneration ( $\mathrm{stems} \geq 0.3 \mathrm{~m}$ tall and $<3.0 \mathrm{~cm} \mathrm{dbh}$ ) in repeatedly burned versus unburned stands following

407 the natural canopy gap creation, presumably due to increased light levels in the forest understory

408 subsequent to the elimination of shade-tolerant species in midstory (stems $3-20 \mathrm{~cm}$ dbh) prior to canopy

409 gap formation. It is becoming clear that to develop large, competitive Oak-Hickory seedlings/saplings in

410 long undisturbed forest stands in a timely manner, prescribed burning must be accompanied by reductions

411 in canopy cover via natural (Hutchinson et al., 2012b) or silvicultural (Brose et al., 1999a; Brose, 2010;

412 Brose, 2013) processes. In our study, it remains uncertain whether the large seedlings and small saplings

413 in the Oak-Hickory group observed in the LFF treatment will be sustained in the long-term as sprouting

414 from top-killed trees remains vigorous (Arthur et al., 2015) and the relative density of non-Oak-Hickory

415 competitors remains high. Similarly, it is unclear whether additional years after cessation of fire in the FF

416 treatments will lead to increases in seedling density. Therefore, should canopy disturbance(s) occur, it is

417 uncertain whether the Oak-Hickory will outcompete the co-occurring competitor species also capable of

418 responding positively to decreased canopy cover (e.g., Tift and Fajvan, 1999).

419 The 80+ years of fire exclusion and limited disturbance in the stands utilized in this study

420 facilitated the development of dense regeneration, sapling, and midstory layers dominated by shade-

421 tolerant, mesophytic species (Arthur et al., 2015). It appears that dormant season fire, even applied 
422 frequently, is ineffective at controlling the density and relative abundance of non-Oak-Hickory species in 423 the woody regeneration layer. Additional treatments including herbicide application of non-Oak-Hickory

424 competitors and/or additional prescribed burns conducted during the growing season may be necessary to 425 reduce the abundance of non-Oak-Hickory competitors in the woody regeneration layer and increase the 426 likelihood of Oak-Hickory recruitment should natural release events occur (Hutchinson et al., 2012b). In

427 the FF treatment where the density of small Oak-Hickory saplings remains similar to unburned areas and 428 in Submesic areas of the LFF treatment, where large Oak-Hickory seedling and small Oak-Hickory

429 sapling density remains low, additional burning during the growing season coupled with silvicultural

430 treatments, such as the oak shelterwood method (Loftis 1990b), the shelterwood/burn technique (Brose et 431 al., 1999a; 1999b), or post-disturbance release burning (Brose et al., 2014) may be necessary to increase 432 regeneration potential and ensure recruitment of Oak-Hickory into the canopy over the long-term.

\section{Acknowledgements}

434 This study was funded by the Joint Fire Sciences Program (Award \#01-3-3-14) and the USDA, Forest 435 Service, Southern Research Station, Upland Hardwood Ecology and Management Work Unit (RWU436 4157). This work is supported by the National Institute of Food and Agriculture, U.S. Department of 437 Agriculture, McIntire-Stennis project under accession number 0220128. This is publication number 16438 09-104 of the Kentucky Agricultural Experiment Station and is published with the approval of the 439 Director. We are grateful to the Daniel Boone National Forest (DBNF) for their continued support of this 440 research. We thank Marcus Wind, Kenny Frick, Brandy Benz, Jacqui Adams, and Tracy Roof for data 441 collection efforts. Assistance with statistical analyses was provided by Stan Zarnoch. This paper was 442 written and prepared by a U.S. Government employee on official time, and therefore, is in the public 443 domain and not subject to copyright.

\section{References}

Abrams, M.D., 1992. Fire and the Development of Oak Forests - in Eastern North-America, Oak Distribution Reflects a Variety of Ecological Paths and Disturbance Conditions. BioScience 42, 346-353. 
Albrecht, M.A., McCarthy, B.C., 2006. Effects of prescribed fire and thinning on tree recruitment patterns

Aldrich, S.R., Lafon, C.W., Grissino-Mayer, H.D., DeWeese, G.G., 2014. Fire history and its relations with land use and climate over three centuries in the central Appalachian Mountains, USA. J. Biogeogr. 41, 2093-2104.

Alexander, H.D., Arthur, M.A., Loftis, D.L., Green, S.R., 2008. Survival and growth of upland oak and co-occurring competitor seedlings following single and repeated prescribed fires. For. Ecol. Manage. 256, 1021-1030.

Arthur, M.A., Paratley, R.D., Blankenship, B.A., 1998. Single and repeated fires affect survival and regeneration of woody and herbaceous species in an oak-pine forest. J. Torrey Bot. Soc. 125, 225-236.

Arthur, M.A., Alexander, H.D., Dey, D.C., Schweitzer, C.J., Loftis, D.L., 2012. Refining the oak-fire hypothesis for management of oak-dominated forests of the eastern United States. J. For. 110, 257-266.

Arthur, M.A., Blankenship, B.A., Schörgendorfer, A., Loftis, D.L., Alexander, H.D., 2015. Changes in stand structure and tree vigor with repeated prescribed fire in an Appalachian hardwood forest. For. Ecol. Manage. 340, 46-61.

Arthur, M.A., Blankenship, B.A., Schorgendorfer, A., Loftis, D.L., Alexander, H.D., 2015. Changes in stand structure and tree vigor with repeated prescribed fire in an Appalachian hardwood forest. For. Ecol. Manage. 340, 46-61.

Avers, P.E. 1974. Soil survey of Menifee and Rowan Counties and Northwestern Morgan County, Kentucky. Soil Conservation Service, Washington, D.C.

Blankenship, B.A., Arthur, M.A., 2006. Stand structure over 9 years in burned and fire-excluded oak stands on the Cumberland Plateau, Kentucky. For. Ecol. Manage. 225, 134-145.

Brose, P.H., 2010. Long-term effects of single prescribed fires on hardwood regeneration in oak shelterwood stands. For. Ecol. Manage. 260, 1516-1524.

Brose, P.H., 2014. Development of prescribed fire as a silvicultural tool for the upland oak forests of the eastern United States. J. For. 112, 525-533.

Brose, P.H., Van Lear, D.H., Cooper, R., 1999a. Using shelterwood harvests and prescribed fire to regenerate oak stands on productive upland sites. For. Ecol. Manage. 113, 125-141.

Brose, P.H., Van Lear, D.H., Keyser, P.D., 1999b. A shelterwood-burn technique for regenerating productive upland oak sites in the Piedmont region. South. J. Appl. For. 23, 158-163.

Brose, P.H., Dey, D.C., Phillips, R.J., Waldrop, T.A., 2013. A meta-analysis of the fire-oak hypothesis, Does prescribed burning promote oak reproduction in eastern North America. For. Sci. 59, 322-334.

Brose, P.H., Dey, D.E., Waldrop, T.A., 2014. The fire-oak literature of eastern North America, Synthesis and Guidelines. Newtown Square, PA: USDA For. Serv. Gen. Tech. Rep. NRS-135. 98 p. 
Buchanan, M.L., Hart, J.L., 2012. Canopy disturbance history of old-growth Quercus alba sites in the eastern United States: Examination of long-term trends and broad-scale patterns. For. Ecol. Manage. 267,

Burns, R.M., Honkala, B.H., 1990. Silvics of North America. vol. 2. Hardwoods. For. Serv. Agric. Handb. 654, USDA, Washington, DC.

Caldwell, P.V., Miniat, C.F., Elliott, K.J., Swank, W.T., Brantley, S.T., Laseter, S.H., 2016. Declining water yield from forested mountain watersheds in response to climate change and forest mesophication. Glob. Change Bio. 22, 2997-3012.

Chiang, J., Arthur, M.A., Blankenship, B.A., 2005. The effects of prescribed fire on gap fraction in an oak forest understory on the Cumberland Plateau. J. Torrey Bot. Soc. 132, 432-441.

Crow, T.R., 1992. Population dynamics and growth patterns for a cohort of northern red oak (Quercus rubra) seedlings. Oecologia 91, 192-200.

Delcourt, H.R., Delcourt, P.A., 1997. Pre-Columbian Native American use of fire on southern Appalachian landscapes. Conserv. Biol. 11, 1010-1014.

Delcourt, P.A., Delcourt, H.R., 1998. The influence of prehistoric human-set fires on oak-chestnut forests in the southern Appalachians. Castanea 63, 337-345.

Delcourt, P.A., Delcourt, H.R., Ison, C.R., Sharp, W.E., Gremillion, K.J., 1998. Prehistoric human use of fire, the eastern agricultural complex, and Appalachian oak-chestnut forests, paleoecology of Cliff Palace Pond, Kentucky. Am. Antiquity 63, 263-278.

Dey, D.C., Guyette, R.P., 2000. Anthropogenic fire history and red oak forests in south-central Ontario. Forestry Chron. 76, 339-347.

Dey, D.C., 2014. Sustaining oak forests in eastern North America: Regeneration and recruitment, the pillars of sustainability. For. Sci. 60, 926-942.

Elliott, K.J., Hendrick, R.L., Major, A.E., Vose, J.M., Swank, W.T., 1999. Vegetation dynamics after a prescribed fire in the southern Appalachians. For. Ecol. Manage. 114, 199-213.

Fesenmyer, K.A., Christensen, N.L., Jr., 2010. Reconstructing Holocene fire history in a southern Appalachian forest using soil charcoal. Ecology. 91, 662-670.

Fei, F.L., Kong, N.N., Steiner, K.C., Moser, W.K., Steiner, E.B., 2011. Change in oak abundance in the eastern United States from 1980 to 2008. For. Ecol. Manage. 262, 1370-1377.

Flatley, W.T., Lafon, C.W., Grissino-Mayer, H.D., LaForest. L.B., 2013. Fire history, related to climate and land use in three southern Appalachian landscapes in the eastern United States. Ecol. Appl. 23, 12501266.

Gragson, T.L., Bolstad, P.V., 2006. Land use legacies and the future of southern Appalachia. Soc. Natur. Resour. 19, 175-190.

Guyette, R.P., Spetich, M.A., Stambaugh, M.C., 2006. Historic fire regime dynamics and forcing factors in the Boston Mountains, Arkansas, USA. For. Ecol. Manage. 234, 293-304. 
Harmon, M.E., 1984. Survival of trees after low-intensity surface fires in Great Smoky Mountains National Park. Ecology. 65, 796-802.

Hart, J.L., Grissino-Mayer, H.D., 2008. Vegetation patterns and dendroecology of a mixed harwood forests on the Cumberland Plateau: Implications for stand development. For. Ecol. Manage. 255, 19601975.

Hart, J.L., Clark, S.L., Torreano, S.J., Buchanan, M.L., 2012. Composition, structure, and dendroecology of an old-growth Quercus forest on the tablelands of the Cumberland Plateau, USA. For. Ecol. Manage. $266,11-24$.

Hollingsworth, T.N., Johnstone, J.F., Bernhardt, E.L., Chapin, F.S., 2013. Fire severity filters regeneration traits to shape community assembly in Alaska's boreal forest. Plos One 8, e56033.

Hutchinson, T.F., Sutherland, E.K., Yaussy, D.A., 2005. Effects of repeated prescribed fires on structure, composition, and regeneration of mixed-oak forests in Ohio. For. Ecol. Manage. 218, 210-228.

Hutchinson, T.F., Yaussy, D.A., Long, R.P., Rebbeck, J., Sutherland, E.K., 2012a. Long-term (13-year) effects of repeated prescribed fires on stand structure and tree regeneration in mixed-oak forests. For. Ecol. Manage. 286, 87-100.

Hutchinson, T.F., Long, R.P., Rebbeck, J., Sutherland, E.K., Yaussy, D.A., 2012b. Repeated prescribed fires alter gap-phase regeneration in mixed-oak forests. Can. J. For. Res. 42, 303-314.

Iverson, L.R., Dale, M.E., Scott, C.T., Prasad, A., 1997. A GIS-derived integrated moisture index to predict forest composition and productivity of Ohio forests (U.S.A.). Landscape Ecol. 12, 331-348.

Iverson, L.R., Yaussy, D.A., Rebbeck, J., Hutchinson, T.F., Long, R.P., Prasad, A.M., 2004. A comparison of thermocouples and temperature paints to monitor spatial and temporal characteristics of landscape-scale prescribed fires. Int. J. Wild. Fire. 13, 311-322.

Iverson, L.R., Hutchinson, T.F., Prasad, A.M., Peters, M.P., 2008. Thinning, fire, and oak regeneration across a heterogeneous landscape in the eastern U.S.: 7-year results. For. Ecol. Manage. 255, 3035-3050.

Jones, R.L. 2005. Plant life of Kentucky, an illustrated guide to the vascular flora. University Press of Kentucky, Lexington, KY, USA.

Knapp, B.O., Stephan, K., Hubbart, J.A., 2015. Structure and composition of an oak-hickory forest after over 60 years of repeated prescribed burning in Missouri, USA. For. Ecol. Manage. 344, 95-109.

Kolb, T.E., Steiner, K.C., McCormick, L.H., Bowersox, T.W., 1990. Growth and biomass partitioning of northern red oak and yellow-poplar seedlings to light, soil moisture and nutrients in relation to ecological strategy. For. Ecol. Manage. 38, 65-78.

Larsen, D.R., Metzger, M.A., Johnson, P.S., 1997. Oak regeneration and overstory density in the Missouri Ozarks. Can. J. For. Res. 27, 869-875.

Littell, R.C., Milliken, G.A., Stroup. W.W., Wolfinger, R.D., Schabenberger, O., 2006. SAS system for mixed models, second edition. Cary, NC: SAS Institute, Inc. 814 p. 
Loftis, D.L., 1983. Regeneration southern Appalachian mixed hardwood stands with the shelterwood method. South. J. Appl. For. 7, 212-217.

Loftis, D.L., 1990a. Predicting postharvest performance of advance red oak reproduction in the southern Appalachian. For. Sci. 36, 908-916.

Loftis, D.L., 1990b. A shelterwood method for regenerating red oak in the southern Appalachians. For. Sci. 36, 917-929.

Lorimer, C.G., Chapman, J.W., Lambert, W.D., 1994. Tall understorey vegetation as a factor in the poor development of oak seedlings beneath mature stands. J. Ecol. 82, 227-237.

McEwan, R.W., Muller, R.N., McCarthy, B.C. 2005. Vegetation-environment relationships among woody species in four canopy-layers in an old-growth mixed mesophytic forest. Castanea 70, 32-46.

McEwan, R.W., Hutchinson, T.F., Long, R.P., Ford, D.R>, McCarthy, B.C., 2007. Temporal and spatial patterns in fire occurrence during the establishment of mixed-oak forests in eastern North America. J. Veg. Sci. 18, 655-664.

McEwan, R.W., Dyer, J.M., Pederson, N., 2011. Multiple interacting ecosystem drivers, toward and encompassing hypothesis of oak forest dynamics across eastern North America. Ecography 34, 244-256.

McNab, W.H., Loftis, D.L., Arthur, M.A., Lyons, J.E. 2007. Evaluation of tree species composition as a tool for classifying moisture regimes in oak forests of eastern Kentucky. In: Buckley, D.S., Clatterbuck, W.K. (Eds.), Proceedings of the Fifteenth Central Hardwood Forest Conference. Asheville, NC: USDA For. Serv. Gen. Tech. Rep. SRS-101. p. 754.

McNab, W.H., Loftis, D.L., 2013. A preliminary test of estimating forest site quality using species composition in a southern Appalachian watershed. In: Guldin, J.M. (Ed.), Proceedings of the $15^{\text {th }}$ Biennial Southern Silvicultural Research Conference. Asheville, NC: USDA For. Serv. E-Gen. Tech. Rep. SRSGTR-175. pp. 95-102.

McShea, W.J., Healy, W.M., Devers, P., Fearer, T., Koch, F.H., Stauffer, D., Waldon, J., 2007, Forestry matters: decline of oaks will impact wildlife in hardwood forests. J. Wildlife Manage. 71, 1717-1728.

Miller, G.W., Kochenderfer, J.N., Fekedulegn, D.B., 2006. Influence of individual reserve trees on nearby reproduction in two-aged Appalachian hardwood stands. For. Ecol. Manage. 224, 241-251.

Myers, J.A., Harms, K.E., 2011. Seed arrival and ecological filters interact to assemble high-diversity plant communities. Ecology. 92, 676-686.

Nowacki, G.J., Abrams, M.D., 2008. The demise of fire and "Mesophication" of forests in the eastern United States. BioScience 58, 123-138.

Oswalt, S.N., Smith, W.B., Miles, P.D., Pugh, S.A., 2014. Forest resources of the United States, 2012: a technical document supporting the Forest Service 2010 updates of the RPA Assessment. Washington, D.C.: USDA For. Serv. Gen. Tech. Rep. WO-91.

Pausas, J.G., Bradstock, R.A., Keith, D.A., Keeley, J.E., 2004. Plant functional traits in relation to fire in 651 
652

653

654

655

656

657

658

659

660

661

662

663

664

665

666

667

668

669

670

671

672

673

674

675

676

677

678

679

680

681

682

683

684

685

686

687

688

689

690

691

692

693

694

695

696

697

698

699

700

701

Peterson, D.W., Reich, P.B., 2001. Prescribed fire in oak savanna: fire frequency effects on stand structure and dynamics. Ecol. Appl. 11, 914-927.

Peterson, D.W., Reich, P.B., 2008. Fire frequency and tree canopy structure influence plant species diversity in a forest-grassland ecotone. Plant Ecol. 194, 5-16.

Rentch, J.S., Fajvan, M.A., Hicks, R.R., 2003a. Oak establishment and canopy accession strategies in five old-growth stands in the Central Hardwood Forest Region. For. Ecol. Manage. 184, 285-297.

Rentch, J.S., Fajvan, M.A., Hicks, R.R., Jr., 2003b. Spatial and temporal disturbance characteristics of oak-dominated old-growth stands in the Central Hardwood Forest Region. For. Sci. 49, 778-789.

Royse, J., Arthur, M.A. Schorgendorfer, A., Loftis, D.L., 2010. Establishment and growth of oak (Quercus alba, Quercus prinus) seedlings in burned and fire-excluded upland forests on the Cumberland Plateau. For. Ecol. Manage. 260, 502-510.

SAS Institute, 2011. SAS Version 9.3. SAS Institute Inc., Cary, NC, USA.

Sander, I.L., 1972. Size of advance reproduction key to growth following harvest cutting. St. Paul, MN: USDA For. Serv. Res. Pap. NC-79. 6 p.

Sander, I.L., Graney, D.L., 1992. Regenerating oaks in the Central States. In: Loftis, D.L., McGee, C.E., (Eds.), Oak regeneration: serious problems, practical recommendations. Asheville, NC: USDA For. Serv. Gen. Tech. Rep. SE-84. pp. 174-183.

Shumway, D.L., Abrams, M.D., Ruffner, C.M., 2001. A 400-year history of fire and oak recruitment in an old-growth oak forest in western Maryland, U.S.A. Can. J. For. Res. 31, 1437-1443.

Schweitzer, C.J., Dey, D.C., 2011. Forest structure, composition, and tree diversity response to a gradient of regeneration harvests in the mid-Cumberland Plateau escarpment region, USA. For. Ecol. Manage. 9, $1729-1741$.

Schweitzer, C.J., Dey, D.C., 2015. The conundrum of creating understory light conditions conducive to promoting oak reproduction: midstory herbicide and prescribed fire treatments. In: Holley, A.G., Conner, K.F., Haywood, J.D., (Eds.), Proceedings of the $17^{\text {th }}$ biennial southern silvicultural research conference. Asheville, NC: USDA For. Serv. e-Gen. Tech. Rep. SRS-203. pp. 45-56.

Signell, S.A., Abrams, M.D., Hovis, J.C., Henry, S.W., 2005. Impact of multiple fires on stand structure and tree regeneration in central Appalachian forests. For. Ecol. Manage. 218, 146-158.

Tift, B.D., Fajvan, M.A., 1999. Red maple dynamics in Appalachian hardwood stands in West Virginia. Can. J. For. Res. 29,157-165.

Van Lear, D.H., Waldrop, T.A., 1989. History, uses, and effects of fire in the Appalachians. Asheville, NC: USDA For. Serv. Gen. Tech. Rep. SE-45. 20 pp.

Waldrop, T.A., Hagan, D.L., Simon, D.M., 2016. Repeated application of fuel reduction treatments in the southern Appalachian Mountains, USA: implications for achieving management goals. Fire Ecol. 12, 2847. 


\section{$702 \quad$ Figure captions}

703 Fig. 1. Woody regeneration by size class and species group in 2002 (pretreatment) and 2015 within the

704 Daniel Boone National Forest, Kentucky.

705 Fig. 2. Absolute density (stems ha ${ }^{-1}$ ) of large seedlings (stems $\geq 0.6 \mathrm{~m}$ tall and $<1.2 \mathrm{~m}$ tall) averaged $(a)$

706 across moisture classes, and (b) across treatments by species group in 2002 and 2015 within the Daniel

707 Boone National Forest, Kentucky. Means followed by similar letters are not significantly different among

708 treatments or moisture classes within a given species group. Within a species group, *indicates a

709 significant difference in large seedling density between years within a given treatment or moisture class.

710 Fig. 3. Absolute density (stems $\mathrm{ha}^{-1}$ ) of large seedlings (stems $\geq 0.6 \mathrm{~m}$ tall and $<1.2 \mathrm{~m}$ tall) averaged

711 across treatments and moisture classes. Means followed by the same letter are not significantly different

712 within a species group. *indicates a significant treatment*year and moisture class*year (see Fig. 2).

713 Fig. 4. Absolute density (stems ha ${ }^{-1}$ ) of small saplings (stems $\geq 1.2 \mathrm{~m}$ tall and $<3.8 \mathrm{~cm}$ dbh) averaged

714 across treatments and moisture classes. Means followed by the same letter are not significantly different

715 within a species group. *indicates a significant treatment*year and/or moisture class*year (see Fig. 5).

716 Fig. 5. (a) Absolute density (stems ha ${ }^{-1}$ ) of small saplings (stems $\geq 1.2 \mathrm{~m}$ tall and $<3.8 \mathrm{~cm}$ dbh) averaged

717 (a) across moisture classes, and (b) across treatments by species group in 2002 and 2015 within the

718 Daniel Boone National Forest, Kentucky. Means followed by similar letters are not significantly different

719 among treatments or moisture classes within a given species group. Within a species group, *indicates a

720 significant increase in small sapling density between years within a given treatment or moisture class. 


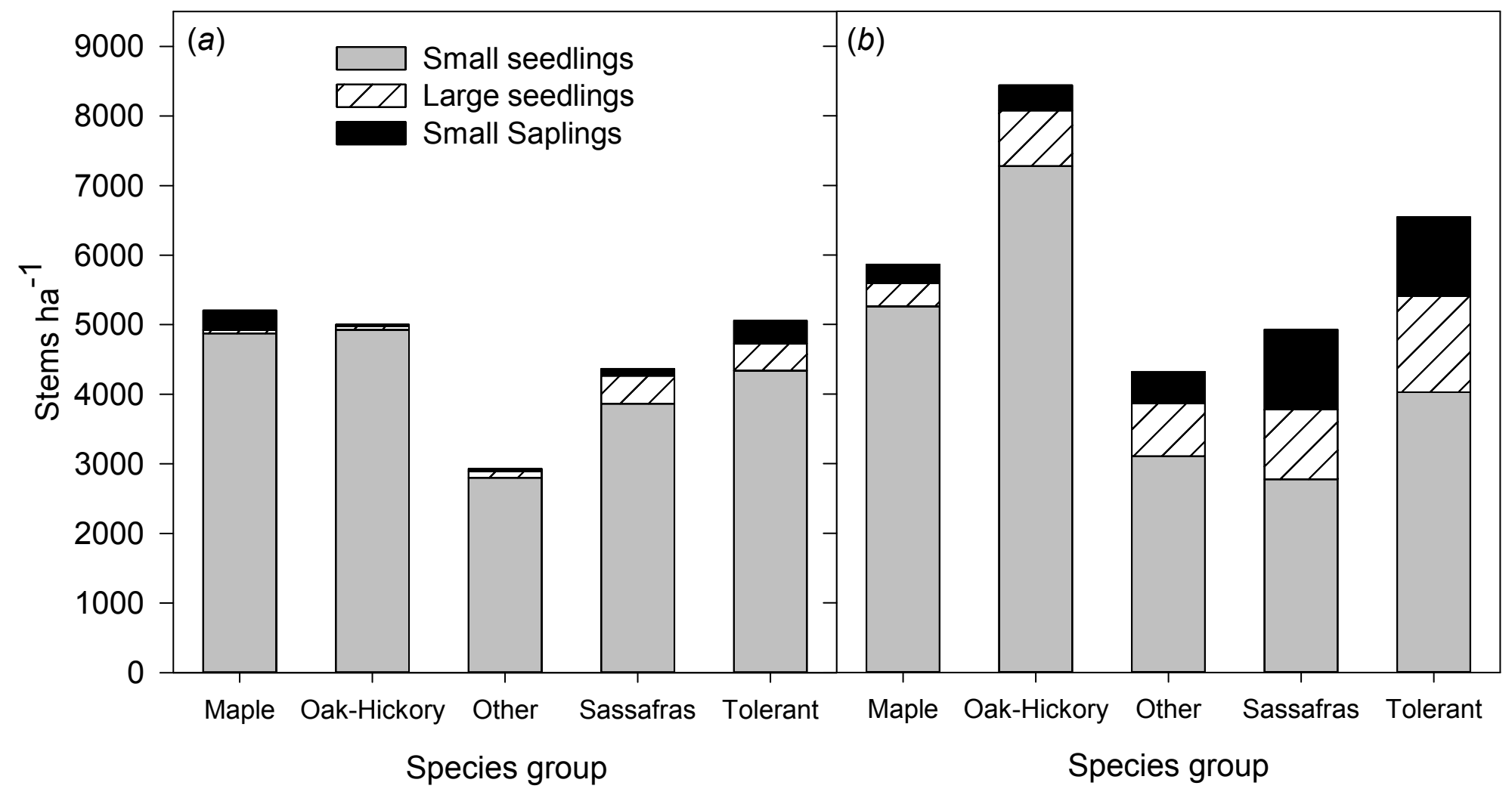




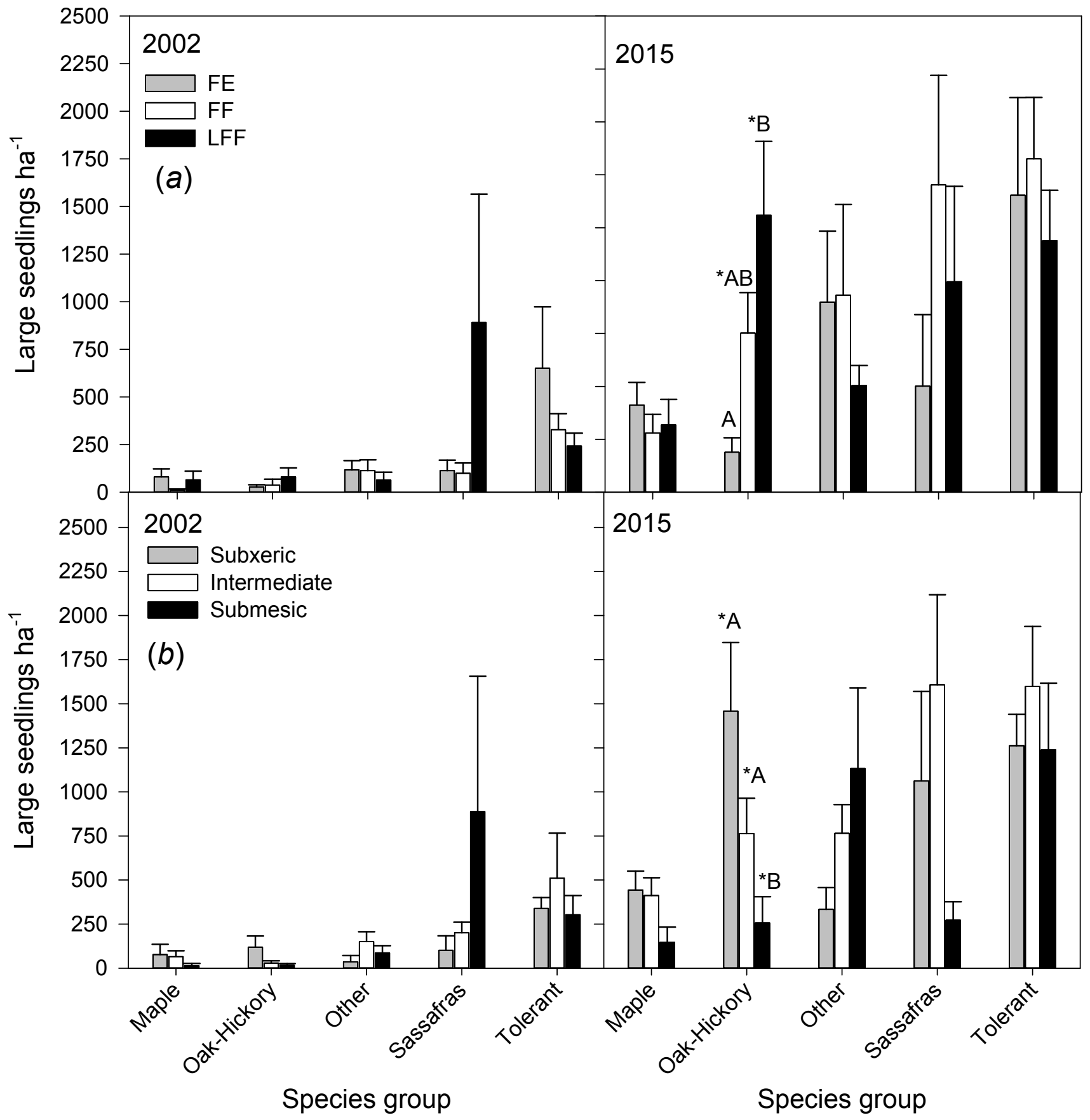




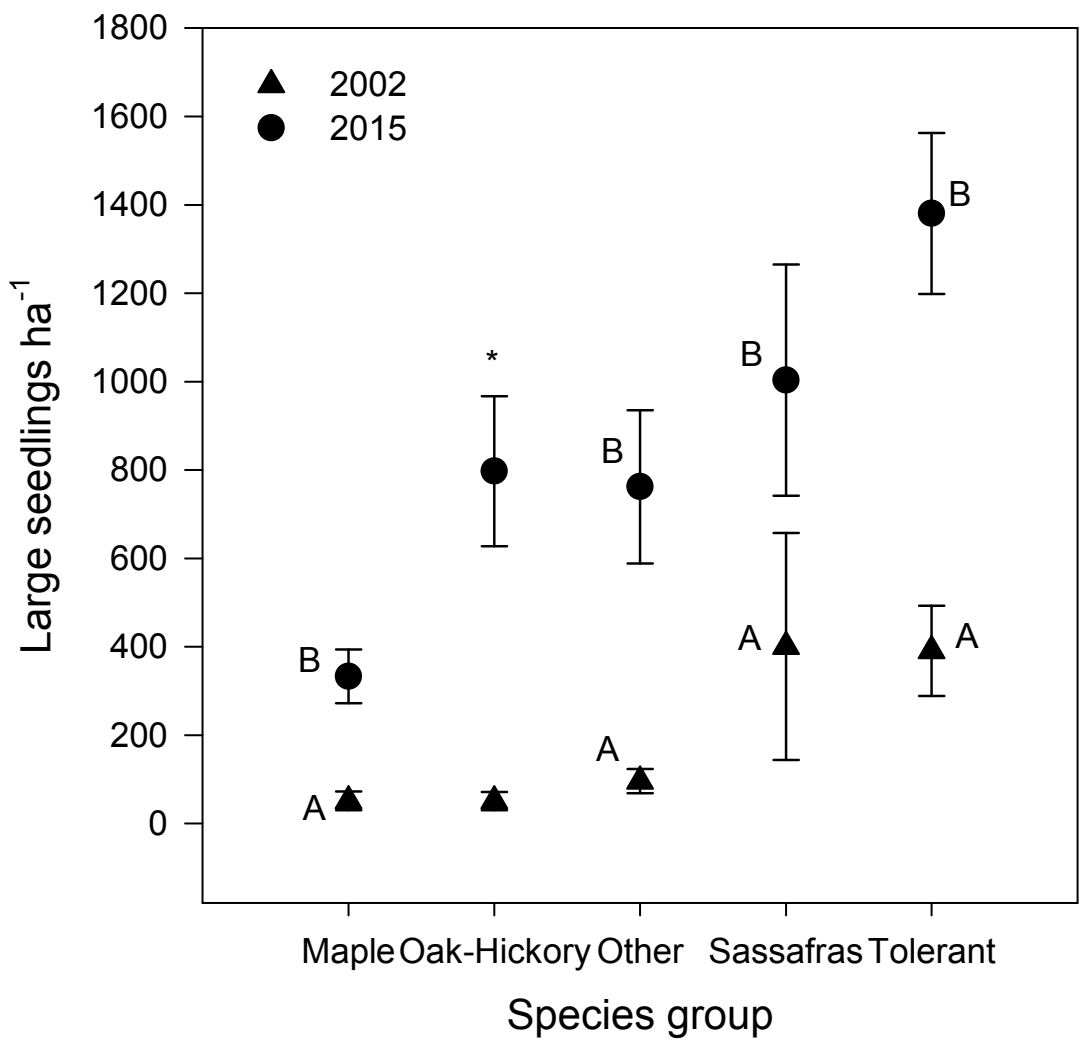




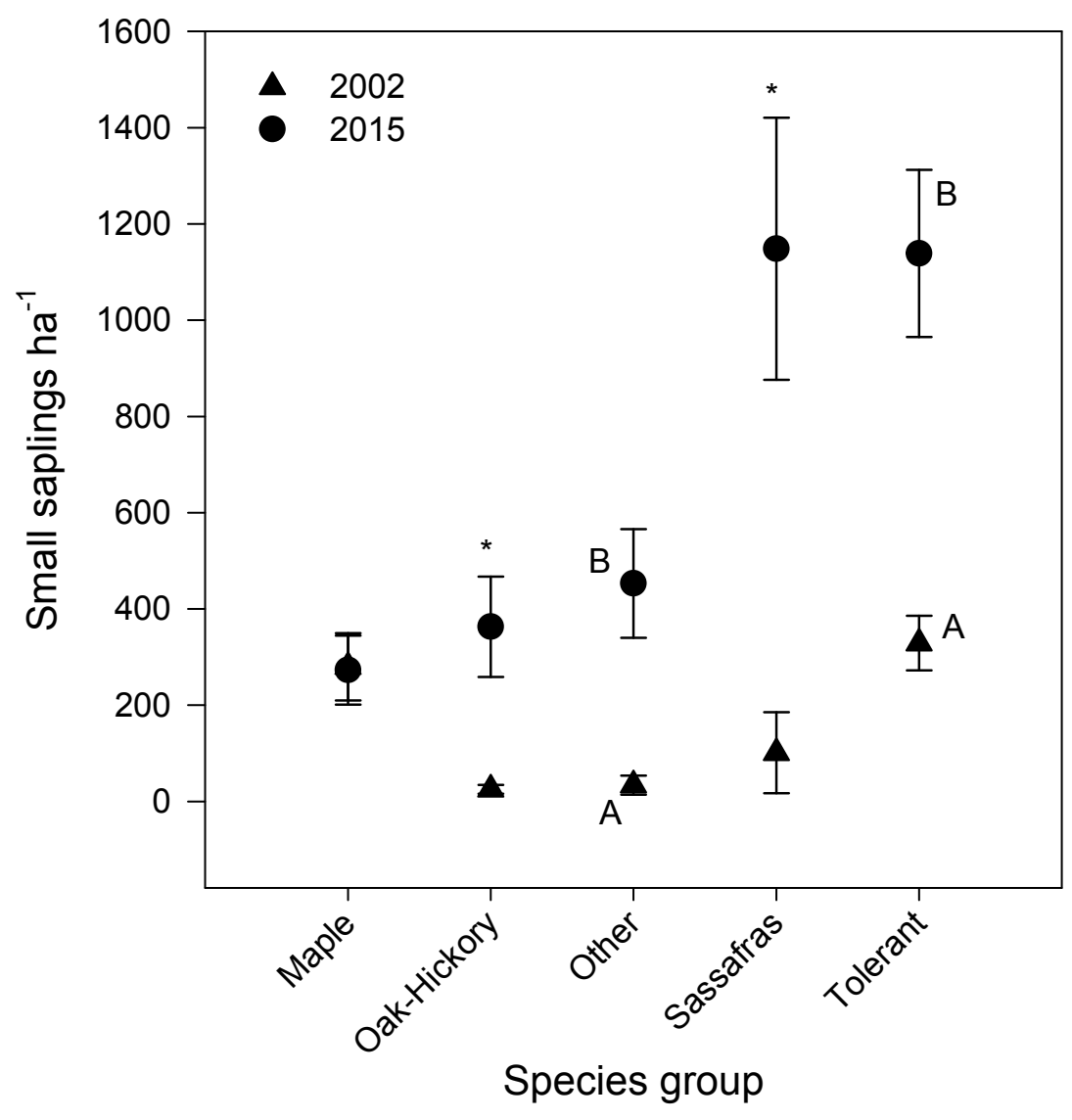




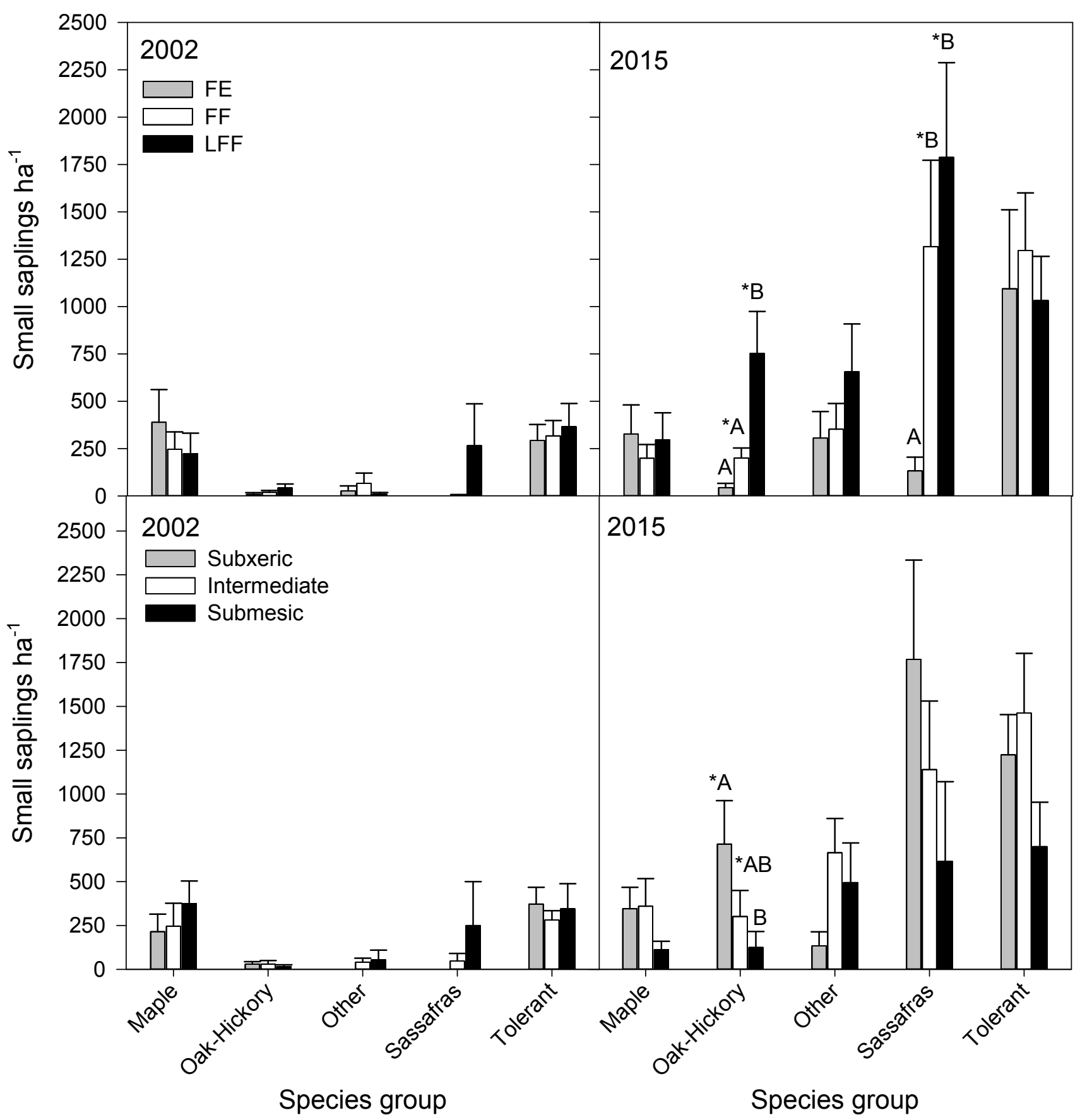


Table 1. Species comprising the Oak-Hickory, Maple, Sassafras, Other, and Tolerant species groups.

\begin{tabular}{|c|c|c|c|c|}
\hline Oak-Hickory & Sassafras & Maple & Other & Tolerant \\
\hline $\begin{array}{l}\text { White oak (Quercus alba) } \\
\text { Scarlet oak (Quercus coccinea) } \\
\text { Chestnut oak (Quercus montana) } \\
\text { Northern red oak (Quercus rubra) } \\
\text { Black oak (Quercus velutina) } \\
\text { Hickory species (Carya) }\end{array}$ & Sassafras (Sassafras albidum) & $\begin{array}{l}\text { Red maple (Acer rubrum) } \\
\text { Sugar maple (Acer saccharum) }\end{array}$ & $\begin{array}{l}\text { White ash (Fraxinus americana) } \\
\text { Cucumbertree (Magnolia accuminata) } \\
\text { American chestnut (Castenea dentata) } \\
\text { Eastern white pine (Pinus strobus) } \\
\text { Sweet birch (Betula lenta) } \\
\text { Black walnut (Juglans nigra) } \\
\text { Yellow-poplar (Liriodendron tulipifera) } \\
\text { Black locust (Robinia pseudoacacia) } \\
\text { Black cherry (Prunus serotina) } \\
\text { Shortleaf pine (Pinus echinata) } \\
\text { Virginia pine (Pinus virginiana) } \\
\text { Umbrella magnolia (Magnolia tripetala) } \\
\text { Blue ash (Fraxinus quadrangulata) } \\
\text { Bigtooth aspen (Populus grandidentata) }\end{array}$ & $\begin{array}{l}\text { Serviceberry (Amalanchier arborea) } \\
\text { Buckeye (Aesculus flava) } \\
\text { Musclewood (Carpinus caroliniana) } \\
\text { Flowering dogwood (Cornus florida) } \\
\text { Elm species (Ulmus) } \\
\text { American beech (Fagus grandifolia) } \\
\text { Hackberry (Celtis occidentalis) } \\
\text { Holly species (Ilex) } \\
\text { Mulberry (Morus rubra) } \\
\text { Blackgum (Nyssa sylvatica) } \\
\text { Ironwood (Ostrya virginiana) } \\
\text { Sourwood (Oxydendrum arboreum) } \\
\text { Pawpaw (Asimina triloba) } \\
\text { Persimmon (Diospyros virginiana) } \\
\text { Eastern redbud (Cercis canadensis) } \\
\text { Alerternate-leaf dogwood (Cornus alternifolia) }\end{array}$ \\
\hline
\end{tabular}


Table 2. $P$-values associated with the split-plot analysis of absolute density (stems ha ${ }^{-1}$ ) of small seedlings, (stems $<0.6 \mathrm{~m}$ tall), large seedlings (stems $\geq 0.6 \mathrm{~m}$ tall and $<1.2 \mathrm{~m}$ tall), and small saplings (stems $\geq 1.2 \mathrm{~m}$ tall and $<3.8 \mathrm{~cm} \mathrm{dbh}$ ) as well as relative density of small saplings by species group in the Danielle Boone National Forest, Kentucky. TRT=treatment (FE, FF, LFF), MC=moisture class (Subxeric,

\begin{tabular}{|c|c|c|c|c|c|c|}
\hline Fixed effect & $\mathrm{df}$ & Maple & Oak-Hickory & Other & Sassafras & Tolerant \\
\hline
\end{tabular}

Intermediate, Submesic), YR=year $(2002,2015)$. 


\begin{tabular}{|c|c|c|c|c|c|c|}
\hline \multirow[b]{2}{*}{ TRT } & \multirow[b]{2}{*}{2} & \multicolumn{5}{|c|}{ Small seedling density $\left(\right.$ stems $\left.\mathrm{ha}^{-1}\right)$} \\
\hline & & 0.9747 & 0.7112 & 0.1945 & 0.3847 & 0.1503 \\
\hline MC & 2 & 0.8183 & 0.0005 & 0.0011 & 0.0056 & 0.5291 \\
\hline $\mathrm{TRT}^{*} \mathrm{MC}$ & 4 & 0.7765 & 0.4372 & 0.3381 & 0.0827 & 0.4811 \\
\hline YR & 1 & 0.0924 & $<0.0001$ & 0.4359 & 0.0133 & 0.3802 \\
\hline TRT*YR & 2 & 0.0743 & 0.4363 & 0.8312 & 0.8179 & 0.7206 \\
\hline MC*YR & 2 & 0.0328 & 0.6274 & 0.1928 & 0.2557 & 0.2125 \\
\hline \multirow[t]{2}{*}{$\mathrm{TRT}^{*} \mathrm{MC} * \mathrm{YR}$} & 4 & 0.7067 & 0.6421 & 0.7471 & 0.5154 & 0.1489 \\
\hline & & \multicolumn{5}{|c|}{ Large seedling density $\left(\right.$ stems ha $\left.{ }^{-1}\right)$} \\
\hline TRT & 2 & 0.4353 & 0.0872 & 0.5481 & 0.5490 & 0.7205 \\
\hline $\mathrm{MC}$ & 2 & 0.1513 & 0.0008 & 0.0398 & 0.3094 & 0.1262 \\
\hline TRT*MC & 4 & 0.9967 & 0.7718 & 0.6942 & 0.9889 & 0.9284 \\
\hline YR & 1 & $<0.0001$ & $<0.0001$ & $<0.0001$ & 0.0198 & $<0.0001$ \\
\hline TRT*YR & 2 & 0.5961 & 0.0438 & 0.5378 & 0.2460 & 0.2586 \\
\hline MC*YR & 2 & 0.0946 & 0.0461 & 0.3148 & 0.1805 & 0.7862 \\
\hline \multirow[t]{2}{*}{ TRT*MC*YR } & 4 & 0.7624 & 0.7090 & 0.2127 & 0.8017 & 0.8181 \\
\hline & & \multicolumn{5}{|c|}{ Small sapling density $\left(\right.$ stems $\left.\mathrm{ha}^{-1}\right)$} \\
\hline TRT & 2 & 0.8246 & $\mathbf{0 . 0 3 8 3}$ & 0.5516 & 0.0100 & 0.9270 \\
\hline $\mathrm{MC}$ & 2 & 0.7084 & 0.0428 & 0.0673 & 0.5304 & 0.1947 \\
\hline $\mathrm{TRT}^{*} \mathrm{MC}$ & 4 & 0.6996 & 0.4292 & 0.9553 & 0.5918 & 0.9394 \\
\hline YR & 1 & 0.8487 & $<0.0001$ & 0.0019 & $<0.0001$ & 0.0007 \\
\hline TRT*YR & 2 & 0.9208 & 0.0104 & 0.4538 & 0.0117 & 0.8949 \\
\hline MC*YR & 2 & 0.3787 & 0.0236 & 0.2623 & 0.0603 & 0.1185 \\
\hline \multirow[t]{2}{*}{$\mathrm{TRT}^{*} \mathrm{MC}^{*} \mathrm{YR}$} & 4 & 0.8164 & 0.3957 & 0.9199 & 0.1712 & 0.2403 \\
\hline & & \multicolumn{5}{|c|}{ Small sapling relative density (\%) } \\
\hline TRT & 2 & 0.6829 & 0.3188 & 0.7436 & 0.0133 & 0.4839 \\
\hline $\mathrm{MC}$ & 2 & 0.9359 & $\mathbf{0 . 0 3 8 8}$ & 0.0467 & 0.6911 & 0.6040 \\
\hline $\mathrm{TRT}^{*} \mathrm{MC}$ & 4 & 0.7447 & 0.7035 & 0.7591 & 0.9765 & 0.8960 \\
\hline YR & 1 & 0.0172 & 0.0028 & 0.0083 & 0.0004 & 0.4072 \\
\hline TRT*YR & 2 & 0.6296 & 0.6821 & 0.6070 & 0.0825 & 0.6492 \\
\hline MC*YR & 2 & 0.7566 & 0.2008 & 0.5054 & 0.5576 & 0.7220 \\
\hline TRT*MC*YR & 4 & 0.6811 & 0.6576 & 0.8554 & 0.5631 & 0.8017 \\
\hline
\end{tabular}


Table 3. Absolute density (stems ha ${ }^{-1}$ ) of small seedlings (stems $<0.6 \mathrm{~m}$ tall) for each species group by year, treatment, and moisture class within the Daniel Boone National Forest, Kentucky. Values represent the mean (standard error). Means followed by the same letter are not significantly different within a given species group. *indicates a significant difference in small seedling density within the Subxeric moisture class between $2002(4128 \pm$

$\left.554 \mathrm{ha}^{-1}\right)$ and $\left.294 \mathrm{ha}^{-1}\right)$.

\begin{tabular}{llllll}
\hline & Maple & $\begin{array}{l}\text { Oak- } \\
\text { hickory }\end{array}$ & Other & Sassafras & Tolerant \\
\hline Year & & & & & \\
2002 & 4872 & $4925^{\mathbf{A}}$ & 2800 & $3865^{\mathbf{A}}$ & 4338 \\
& $(288)$ & $(588)$ & $(439)$ & $(431)$ & $(395)$ \\
2015 & 5259 & $7279^{\mathbf{B}}$ & 3105 & $2775^{\mathbf{B}}$ & 4026 \\
& $(262)$ & $(586)$ & $(488)$ & $(387)$ & $(467)$ \\
\hline Treatment & & & & & \\
FE & 5326 & 5504 & 4099 & 3176 & 5581 \\
& $(302)$ & $(855)$ & $(609)$ & $(610)$ & $(450)$ \\
FF & 4938 & 6460 & 3225 & 3075 & 4349 \\
& $(337)$ & $(898)$ & $(635)$ & $(511)$ & $(528)$ \\
LFF & 4977 & 6250 & 1818 & 3650 & 2945 \\
& $(363)$ & $(607)$ & $(324)$ & $(465)$ & $(398)$ \\
\hline Moisture class & & & & & \\
Subxeric & $4836^{*}$ & $7884^{\mathbf{A}}$ & $1247^{\mathbf{A}}$ & $3832^{\mathbf{A}}$ & 3387 \\
& $(360)$ & $(822)$ & $(425)$ & $(532)$ & $(423)$ \\
Intermediate & 5200 & $7121^{\mathbf{A}}$ & $2938^{\mathbf{B}}$ & $4100^{\mathbf{A}}$ & 4256 \\
& $(254)$ & $(576)$ & $(423)$ & $(418)$ & $(442)$ \\
Submesic & 5115 & $3397^{\mathbf{B}}$ & $4461^{\mathbf{C}}$ & $1995^{\mathbf{B}}$ & 4793 \\
& $(414)$ & $(420)$ & $(557)$ & $(465)$ & $(646)$ \\
\hline
\end{tabular}


Table 4. Relative density (\%) of a given species group within the small sapling (stems $\geq 1.2 \mathrm{~m}$ tall and $<3.8 \mathrm{~cm} \mathrm{dbh}$ ) by year, treatment, and moisture class within the Daniel Boone National Forest, Kentucky. Values represent the mean (standard error). Means followed by the same letter are not significantly different within a given species group.

\begin{tabular}{llllll}
\hline & Maple & $\begin{array}{l}\text { Oak- } \\
\text { hickory }\end{array}$ & Other & Sassafras & Tolerant \\
\hline Year & $33.2^{\mathbf{A}}$ & $3.3^{\mathbf{A}}$ & $3.2^{\mathbf{A}}$ & $6.3^{\mathbf{A}}$ & 49.8 \\
2002 & $(6.4)$ & $(1.2)$ & $(1.7)$ & $(4.4)$ & $(6.6)$ \\
& $11.7^{\mathbf{B}}$ & $8.4^{\mathbf{B}}$ & $12.0^{\mathbf{B}}$ & $27.4^{\mathbf{B}}$ & 40.5 \\
2015 & $(3.6)$ & $(1.8)$ & $(2.6)$ & $(5.5)$ & $(5.3)$ \\
\hline Treatment & & & & & \\
FE & 35.0 & 2.4 & 6.1 & $2.5^{\mathbf{A}}$ & 53.9 \\
& $(8.4)$ & $(1.3)$ & $(2.5)$ & $(1.5)$ & $(7.9)$ \\
FF & 21.6 & 4.7 & 7.8 & $20.6^{\mathbf{B}}$ & 45.3 \\
& $(6.8)$ & $(1.3)$ & $(3.0)$ & $(7.4)$ & $(6.4)$ \\
LFF & 13.4 & 9.5 & 8.6 & $24.7^{\mathbf{B}}$ & 38.2 \\
\hline Moisture class & $(5.0)$ & $(2.4)$ & $(3.2)$ & $(7.0)$ & $(7.5)$ \\
\multirow{2}{*}{ Subxeric } & 18.6 & $10.6^{\mathbf{A}}$ & $1.4^{\mathbf{A}}$ & 16.8 & 45.5 \\
& $(5.8)$ & $(2.6)$ & $(0.8)$ & $(6.2)$ & $(7.1)$ \\
Intermediate & 20.6 & $5.0^{\mathbf{A B}}$ & $10.8^{\mathbf{B}}$ & 16.3 & 47.3 \\
& $(5.6)$ & $(1.7)$ & $(2.7)$ & $(5.3)$ & $(6.7)$ \\
Submesic & 27.9 & $2.6^{\mathbf{B}}$ & $9.5^{\mathbf{A B}}$ & 17.6 & 42.4 \\
& $(8.9)$ & $(1.2)$ & $(3.7)$ & $(8.5)$ & $(8.6)$ \\
\hline
\end{tabular}

